\title{
An Overview of the Advantages of Digital Flexible Ureteroscopes. A Review by Young Academic Urologists Endourology and Urolithiasis Working Party of the European Association of Urology
}

\author{
Dijital Fleksibl Üreteroskopların Avantajları
}

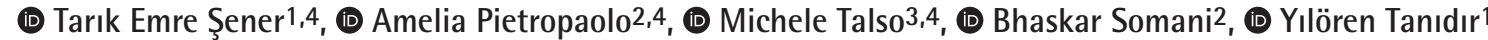 \\ Young Academic Urologists (YAU) "Endourology and Urolithiasis" Working Party4 \\ ${ }^{1}$ Marmara University Hospital, Clinic of Urology, Istanbul, Turkiye \\ 2 University Hospital Southampton NHS Trust, Clinic of Urology, Southampton, United Kingdom \\ ${ }^{3}$ ASST Vimercate Hospital, Clinic of Urology, Monza Brianza, Italy \\ ${ }^{4}$ European Association of Urology, Young Academic Urologists, Urology, Arnhem, Netherlands
}

\section{What's known on the subject? and What does the study add?}

A vast evidence-based knowledge is available in the literature. Different characteristics of different flexible ureteroscopes have been studied by many authors, high quality articles have been published since the introduction of the first flexible ureteroscopes. However, new technologies emerge each day. The previous studies have become only a part of the history. This review highlights the important differences among both the historic and the modern-era flexible ureteroscopes. It also creates a short summary of what endourologists should know in terms of technical aspects.

\begin{abstract}
Endoscopic technology is the cream of the crop for the urinary tract endoscopic procedures in our modern era of surgery. The idea of this review was to evaluate different characteristics of fiberoptic (FO), reusable digital (D) and disposable digital flexible ureteroscopes (FUs) and have an understanding of different comparisons in-between. The topics covered in this review comprise the visual characteristics, weight, costs, durability, and maneuverability aspects and size characteristics of different endoscopes. Digital FUs provide various advantages especially in terms of visual quality and durability. The new generation D-FUs also have excellent maneuverability, similar to FO ureteroscopes, but they are larger in size, which in turn can affect morbidity due to increased post-operative stenting and increased complication risk with larger ureteral access sheat and they come with higher costs.

Many endourologists may prefer to use these high-tech, sophisticated devices as first line for their flexible ureteroscopy procedures as they provide excellent surgical outcomes. However, due to excellent maneuverability advantages in complicated anatomies, smaller sizes and lower costs, endourologists should always try to keep a FO FU ready for action in their operating rooms.
\end{abstract}

Keywords: Flexible ureteroscopy, Endourology, Technology

Öz

Endoskopik teknoloji, modern cerrahi çağımızda üriner sistem endoskopik prosedürleri için en ileri teknolojik girişimleri mümkün kılmaktadır. Bu derleme ile, fiberoptik (FO), tekrar kullanılabilir / "disposable" dijital (D) ve tek kullanımlık dijital esnek / "fleksibl" üreteroskopların (FU) farklı özelliklerini değerlendirmek ve aralarındaki farklı karşılaştırmaları anlamaktır. Bu derlemede ele alınan konular, farklı endoskopların görsel özelliklerini, ağırlığını, maliyetlerini, dayanıklılı̆ını, manevra kabiliyetlerini ve boyut özelliklerini içermektedir. Dijital esnek üreteroskoplar, özellikle görsel kalite ve dayanıklııı açısından çeşitli avantajlar sağlar. Yeni nesil D-FU'lar aynı zamanda fiberoptik üreteroskoplara benzer şekilde mükemmel manevra kabiliyetine sahiptir, ancak daha büyük boyuttadırlar, bu da daha büyük üreteral giriş kılıfları ile artan post-operatif stentleme ve artan komplikasyon riski nedeniyle morbiditeyi etkileyebilir ve daha yüksek maliyetlere sebep olabilir. Birçok endoürolog, "fleksibl" üreteroskopi ameliyatları için esnek

Correspondence: Tarık Emre Şener, Marmara University Hospital, Clinic of Urology, İstanbul, Turkiye

E-mail: dr.emresener@gmail.com ORCID-ID: orcid.org/0000-0003-0085-7680

Received: 10.01.2020 Accepted: 23.01.2020

Cite this article as: Şener TE, Pietropaolo A, Talso M, Somani B, Tanidir Y, Young Academic Urologists (YAU) "Endourology and Urolithiasis" Working Party. An Overview of the Advantages of Digital Flexible Ureteroscopes. A Review by Young Academic Urologists Endourology and Urolithiasis Working Party of the European Association of Urology. J Urol Surg 2020;7(2):76-82.

๑Copyright 2020 by the Association of Urological Surgery / Journal of Urological Surgery published by Galenos Publishing House. 
üreteroskopi prosedürleri için bu yüksek teknoloji ürünü, sofistike cihazları kullanmayı tercih edebilir. Bununla birlikte, karmaşık anatomilerde mükemmel manevra kabiliyeti avantajları, daha küçük boyutlar ve daha düşük maliyetler nedeniyle, endoürologlar her zaman fiberoptik esnek bir üreteroskopu ameliyat odalarında çalışmaya hazır tutmalıdır.

Anahtar Kelimeler: Esnek üreteroskopi, Endoüroloji, Teknoloji

\section{Introduction}

Digital endoscopic technology is the cream of the crop for the urinary tract endoscopic procedures in our modern era of surgery. Historically, the pioneers probably did not even dream about reaching out to our resources, but they knew they had to start innovating. It all started with Bozzini and "the Lichtleiter" that physicians were able to look inside a body cavity with the help of a candlelight. Then Antonin Desormeaux, who was known as the "father of endoscopy", introduced the term "I'endoscopie" with his new instrument, "the endoscope". But particularly, the endoscopes started to resemble what we are using today with the development of Nitze's cytoscope in 1876 (1). After these early steps of endoscopic diagnosis, it was Jean Civiale, a French surgeon, who started out urological endourological procedures with the treatment of bladder stones, without the necessity of an open surgery (2).

It is only possible by acknowledging the past that we can appreciate what we have today. We should be very keen on understanding the different characteristics of the devices that we have on our tables, in order to obtain the maximal usefulness.

The idea of this review was to evaluate different characteristics of fiberoptic (FO), reusable digital (D) and disposable digital flexible ureteroscopes (FUs) and have an understanding of different comparisons in-between (Figure 1). The topics covered in this review comprise the visual characteristics, weight, costs, durability and maneuverability aspects and size characteristics of different endoscopes.

\section{Visual Characteristics}

At the beginning of endoscopic surgery, we had rod lenses, which led to development of rigid devices. In these rod lenses, glass cylinders were placed within the telescope and were aligned with precision. There were air gaps between the cylinders, which served as the lenses (Figure 2). Then came out the FO technology, which provided better visual quality, and also the development of FO semirigid and flexible devices back in 1960's. Hopkins developed a method of transmitting images and light, down a bundle of transparent fibers assembled as a cable, which were then coated with another transparent material with a different refractive index. This development added the option of being "flexible" and more durable to these endoscopes. Then Marshall published the first article entitled "Fiber Optics in Urology" in 1964 (3). The first flexible upper tract endoscopy was performed in 1970's, and the article was published in 1971 by Takayasu et al. (4) with the title "Clinical Application of Fiber-optic pyeloureteroscope". Even disposable ureteroscopes were on the table almost 30 years ago before the new modern devices were launched. The article entitled "Flexible ureteropyeloscopy with modular, "disposable" endoscope" was published by Bagley (5) in 1987.

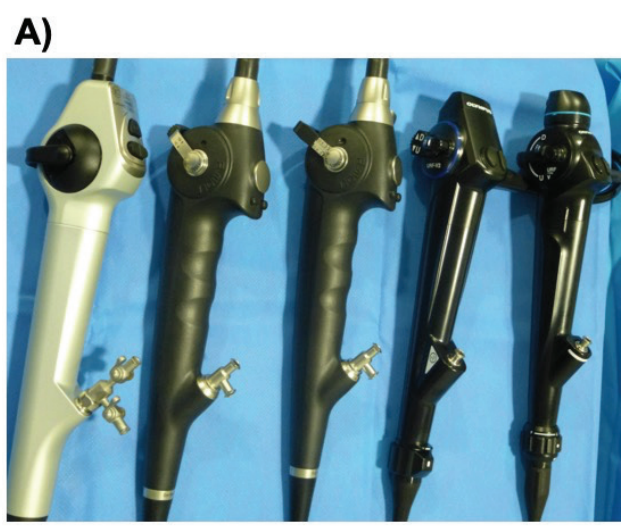

B)

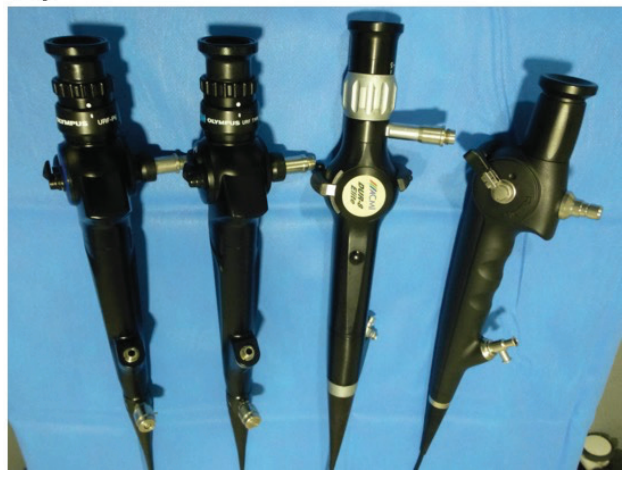

Figure 1. A) Digital Flexible Ureteroscopes, B) Fiberoptic Flexible Ureteroscopes

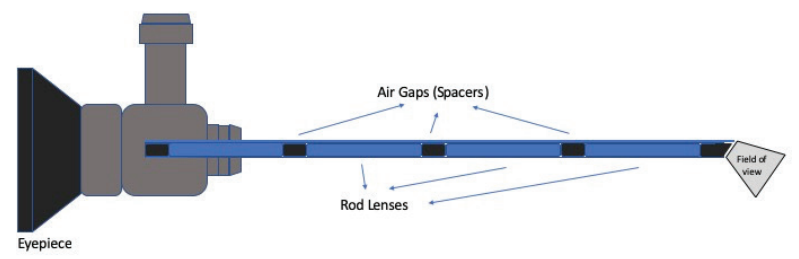

Figure 2. Schematic drawing of the inside of a rod lens endoscope 
The image quality of these first endoscopes was primitive and impossible to compare to what we have in our hands today. The visual quality of FO FUs are not as good as the semirigid ureteroscopes due to "Moiré" effect, which is the interference caused by a periodically repetitive image (dot matrix of the ureteroscopic FO image) superimposed on a second nonidentical periodically repetitive image (dot matrix of the TV monitor). The interference is generated as a result of a multiplicative superposition rule and is especially more significant with endoscopes that have a smaller number of pixels.

Today we have the "digital image" technology which came out in 2008 with the digital flexible ureteroscope ACMI DUR-D ${ }^{\circledR}$ (Southborough, MA, USA) (6). The digital endoscopes have their digital image capturing sensor and their LED illumination at the tip of the ureteroscope transmitting the data to the proximally placed processor; hence they are called to have the "chip-onthe-tip" technology. This ureteroscope, with its nitinol shaft construction and the lack of fibers passing inside the endoscope, was claimed to be more durable than conventional FO FUs. The breakthrough improvement was the visual image quality, which was referred to as "excellent" by the authors. After this noncomparative article, in 2008, Andonian et al. (7) published their study of visual comparison between the FO and the digital FUs, ACMI DUR8 ${ }^{\circledR}$ (Southborough, MA, USA) and ACMI DUR-D ${ }^{\circledR}$, respectively. The pictures of a specific test card were taken with both ureteroscopes and with the FO ureteroscope, the image was referred to as "grainy" and had low resolution compared to the digital ureteroscope, which had more brightness and significantly higher resolution. The digital ureteroscope was able to delineate the smallest markings on the test card (7).

The comparisons of FO and digital ureteroscopes continued throughout years. Al-Qahtani et al. (8) evaluated Olympus URF$V^{\circledR}$ (Olympus Europe, Hamburg, Germany) on 60 patients and claimed that when compared to a conventional FO ureteroscope, Olympus URF-V ${ }^{\circledR}$ has high-quality endoscopic images that can improve therapeutic and diagnostic abilities.

In another comparative article by Multescu et al. (9), the authors compared 2 digital FUs; Storz Flex-XC ${ }^{\circledR}$ (Karl Storz, Tuttlingen, Germany) and Olympus URF-V ${ }^{\circledR}$ with 1 FO FU; Wolf Cobra ${ }^{\circledR}$ (Richard Wolf, Knittlingen, Germany). The visibility was scored by the authors on a scale of 5 ; with 1 being "very poor" and 5 being "excellent". The visibility score of 2 digital endoscopes were similar and FO ureteroscope had a significantly lower visibility score. Between the 2 digital ureteroscopes, Olympus URF-V ${ }^{\circledast}$ had the largest clear endoscopic image. At the end of 30 consecutive procedures with each ureteroscope, the digital ureteroscopes maintained the good image quality, whereas the FO ureteroscope had 58 broken fibers, which caused 58 black dots on the screen. The authors concluded that some existing problems have been solved with the new digital FUs (9).
One of the most extensive studies about quality of vision came out in 2018 by PETRA Urogroup. Talso et al. (10) used 7 different FUs (5 D-FU and 4 FO-FU) in various bench models creating 96 videos. Videos with saline, with betadine and with contrast were made; 2 standardized grids and 3 different types of stones were used for assessments. The results showed that Stoz Flex $\mathrm{XC}^{\circledast}$ (Clara Chroma) provided the best image quality. The older version of D-FU of Olympus, Olympus URF-V ${ }^{\circledR}$ was better than Olympus URF-V2 ${ }^{\circledR}$ (Olympus Europe, Hamburg, Germany). Boston Scientific Lithovue ${ }^{\circledR}$ (Boston Scientific, Marlborough, USA) was better than Olympus URF-V2 ${ }^{\circledR}$ and Wolf Cobra Vision ${ }^{\circledR}$ (Richard Wolf, Knittlingen, Germany), which were comparable. D-FU had better overall results compared to FO-FU (10).

Visual quality provides not only a better surgical experience but also decreases the overall operative time. Somani et al. (11) operated 118 patients with either a D-FU (Olympus UFR$\mathrm{V}^{\circledR}$ ) or a FO-FU [Olympus URF-P5 ${ }^{\circledR}$ (Center Valley, PA)]. They demonstrated in their study that even all the remaining variables were similar, the mean operative time was significantly longer in FO-FU group (53.8 vs. 44.5 min).

A table comparing the aforementioned studies and the characteristics mentioned within those studies is provided (Table 1.)

\section{Weight}

In CROES Ureteroscopy Global Group's study including 11885 patients undergoing both semi-rigid and flexible ureteroscopy, the mean operation duration was 48.6 min (12) and in another study from the same group led by Skolarikos, the mean operative time was 59.4, 77.4 and $111.1 \mathrm{~min}$ for stones less than $10 \mathrm{~mm}$, between 10 and $20 \mathrm{~mm}$ and more than $20 \mathrm{~mm}$, respectively. Larger the stones, higher the time duration the surgeon spends with the FU on his/her hands, which may ultimately cause fatigue. That is why, the weight of the device the endourologists hold in their hands is important. With the FO-FU, the addition of the light cable and the camera head's weights further increases the total amount of burden on our hands. This is where the advantage of the D-FU comes in. Proietti et al. (13) evaluated in their study, the weights of different D-FUs and the combination of light cable - camera head - FO-FU. Individually, the FO-FUs, without their attachments, are lighter than the D-FU. The mean weight of the FO-FUs is $335.2 \mathrm{~g}$ while the mean weight of D-FUs is $699.6 \mathrm{~g}$. However, when the light cable and especially the camera heads are attached, the weights are between $810 \mathrm{~g}$ (Olympus OTV-S7 OTV-S7H-1D-L08E ${ }^{\circledR}$ and Storz Flex X2 ${ }^{\circledR}$ ) and $1474 \mathrm{~g}$ (Wolf 3 Chip HD Kamera KOPF Endocam Logic HD ${ }^{\circledR}$ and Wolf Cobra ${ }^{\circledR}$ ). The heaviest D-FU is the Olympus URF-V2 with $942.5 \mathrm{~g}$. However, the measurements of the D-FUs are made as a whole unit, including its cable, of which most of the volume and the weight is attached to the endoscopic processor and not held 
by the surgeon. The disposable FU, Boston Scientific LithoVue ${ }^{\circledR}$ represents the lightest FU among these 12 FUs, with $277.5 \mathrm{~g}$ (13).

\section{Cost}

Endourological procedures depend very much on costly technological equipment. When the delicate nature of the FUs is considered, continuity of clinical practice with these expensive instruments whether when a new endoscope is on the market or when current endoscopes need repair, need strong financial power. The market prices for D-FUs are higher than FO-FUs but the cost of a Flexible Ureteroscopy (FURS) operation has many subcategories such as cleaning and sterilization, operating room usage and endoscope maintenance. These subcategory costs do not exist with disposable devices.

Temiz et al. (14) performed a comparison study of a D-FU and a FO-FU on 105 patients with 54 procedures with FO and 51 with D-FU until both devices were sent for renovation. The sterilization was performed by immersing the endoscopes into Cidex ${ }^{\mathrm{TM}}$ solution. Both endoscopes were used until major damages occurred such as significant deterioration in vision, maneuverability, deflection or a positive pressure leak. Net purchase prices along with calculation of cost/case and cost/per minute working time calculated via case number and average procedure time were evaluated. Mean stone sizes and mean operation durations were similar between 2 groups. Purchase prices were 29500 USD for FO-FU and 58000 USD for D-FU and per-case cost was 549.29 USD for FO-FU and 1137.25 USD for D-FU. Per-minute working time costs, which were calculated by dividing the purchase price to the mean operative duration $\left(38.21{ }^{\circledR} 7.15\right.$ for Flex $X 2{ }^{\circledR}$ and $39.42{ }^{\circledR} 9.38$ for Cobra vision ${ }^{\circledR}$ ), were 772.04 and 1471.33 USD for FO and D-FU, respectively. The authors concluded that D-FU does not provide additional benefit in terms of surgical outcomes, however, it comes at a greater cost (14) (Table 2).

Another study evaluated the cost-analysis between a disposable D-FU and a reusable FO-FU. Taguchi et al. (15) calculated the cost-per-case as follows; operating room cost + labor costs of reprocessing + consumable costs for reprocessing + URS repair costs + URS acquisition costs. Of a series of 23 cases, 14 of

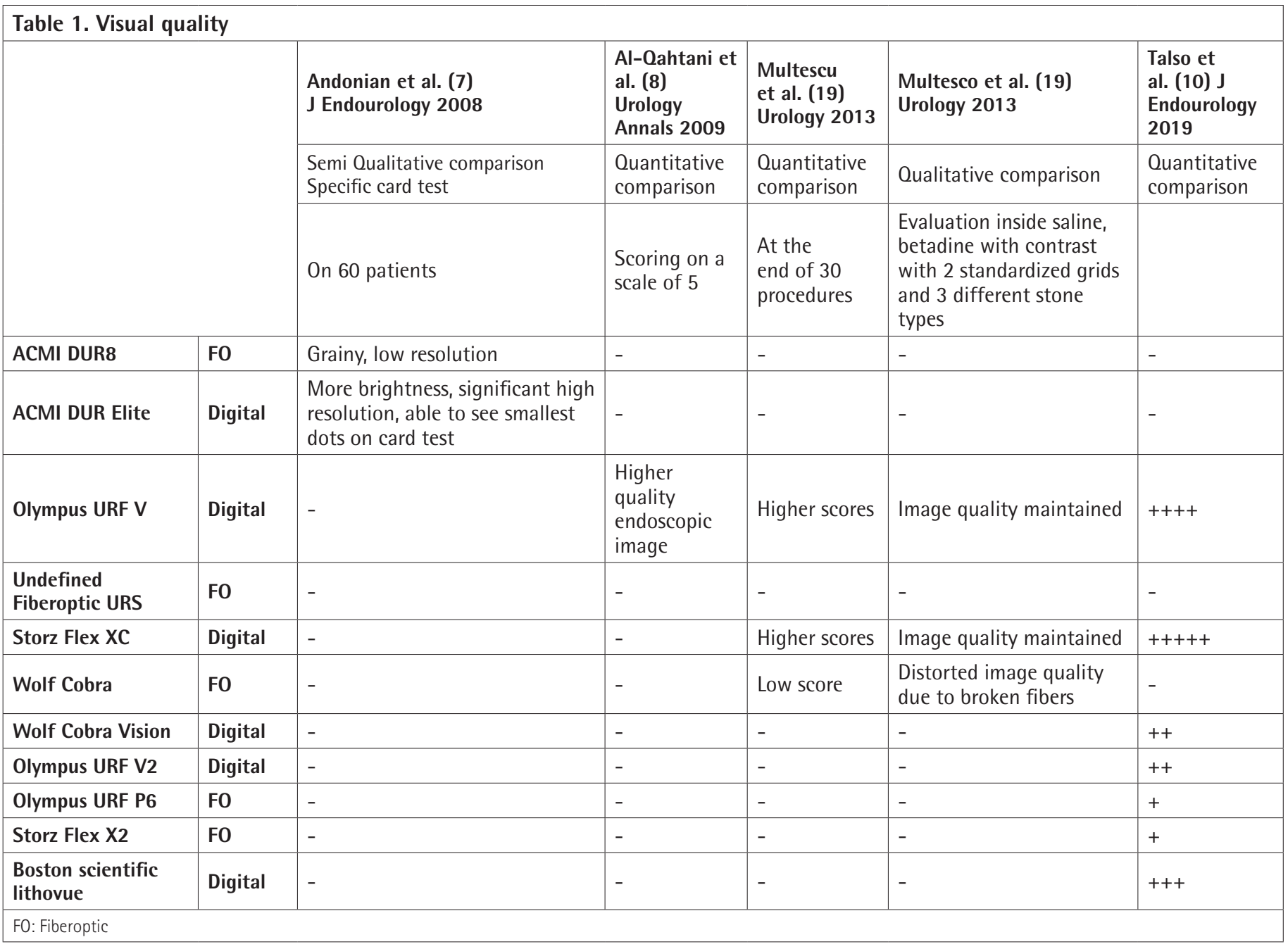


Table 2. Cost

\begin{tabular}{|c|c|c|c|c|}
\hline & & Fiberoptic URS & Re-usable Digital URS & Disposable Digital URS \\
\hline \multirow{2}{*}{ Per-case cost (US dollars) } & $\begin{array}{l}\text { Temiz et al. (14) Urologia } \\
\text { Internationalis } 2019\end{array}$ & 549.29 & 1137.25 & - \\
\hline & Taguchi et al. (15) J Endourology 2018 & 2799.72 & - & 2852.29 \\
\hline
\end{tabular}

them were performed with FO-FU and 9 were performed with $D-F U$. The mean duration of URS set-up was significantly lower with D-FU (2.5 min vs. $5 \mathrm{~min}, \mathrm{p}<0.05)$. The total procedure time and FU use duration were similar between 2 groups. The average labor time for reusable FO-FU reprocessing cycles was $20.9 \mathrm{~min}$ for cable/ureteroscope decontamination, $19.6 \mathrm{~min}$ for cleaning and quality check, 6.5 min for assembly, and 10.3 min for sterilization. Also automated machine processes took an average of $265.6 \mathrm{~min}$ to finish the reprocessing. According to these data, the cost for each cycle of FO-FU reprocessing was 44.23 USD. However, average labor time for disposable D-FU was $4.4 \mathrm{~min}$ for recycling and $03 \mathrm{~min}$ for direct trash disposal. Total cost of labor for disposable D-FU disposal was 3.65 USD. The operation room usage cost was similar between the 2 FUs. The cost of ureteroscope repair and acquisition per case was 957.71 USD and 116.02 USD, respectively. The cost of ureteroscope acquisition was 1500 USD for D-FU. According to these results, the total per case cost was similar between 2 groups, being 2799.72 USD and 2852.29 USD for FU and D-FU, respectively (15) (Table 2).

The results of these previously mentioned studies suggest that costs per case are higher in reusable D-FU than reusable FO-FU, which have similar costs with disposable D-FU.

\section{Durability}

The miniaturization and sophistication of endoscopes makes them vulnerable to external damages. These damages that require repair or sometimes total dysfunction of the endoscope can be various in nature; damage to the working channel, failure to maintain pressure inside the shaft of the endoscope, loss of deflection, pixel losses, etc. However, studies throughout the literature have different definitions about endoscope durability. Some define this as the number of procedures until the endoscope needs any kind of repair and some define as the number of procedures that can be performed until the FU can no longer be used.

The first study about functional durability of FUs was published in 2000 by Afane et al. (16) The authors compared 4 FUs from 4 different manufacturers; Storz, ACMI, Olympus and Wolf, for luminosity, irrigant flow, number of broken image fibers and active deflection over 92 ureteroscopies. Visibility and maneuverability were favorably assessed in all ureteroscopes. Active deflection deterioration was seen between 2\% and 28\% per use. The main reason to send the device to manufacturer was the progressive loss of deflection. In most of the repair cases, the damage occurred during the procedure, whereas damage during cleaning and sterilization was seen in 2 cases. The authors commented that the endoscopes $<9 \mathrm{Fr}$ require further development to improve durability (16). In another study by Monga et al. (17), 192 ureteroscopies with 7 FUs were performed. The mean number of use before repair was lowest for Wolf 7325 and highest for ACMI-DUR-8 Elite ${ }^{\circledast}$ with 14.4 uses. Average minutes with instrument in working channel before a major repair was needed was highest with Olympus URF-P3 ${ }^{\circledR}$ (Olympus Europe, Hamburg, Germany). Of the 10 reasons for sending the device for major repair, 8 was poor visibility, a generalized blurred image. Subjective evaluation of visibility at baseline was highest for ACMI-DUR-8 Elite $^{\circledR}$ and Olympus URF-P3 ${ }^{\circledR}$ and was highest at the time of repair for Storz Flex-X. At the time of repair, maneuverability was highest for Storz Flex-X $2^{\circledR}$ (17). In 2005, Knudsen et al. (18) compared Wolf Viper ${ }^{\circledR}$ (Vernon Hills, IL), Olympus URF-P5 ${ }^{\circledR}$, Gyrus-ACMI DUR-8 ${ }^{\circledR}$ and Stryker FlexVision U-500 ${ }^{\circledR}$ (San Jose, CA) for durability. Forty-two percent of the repairs were because of poor visibility, 25\% due to decreased maneuverability, 25\% due to water leak, and $8 \%$ due to accidental laser firing inside the device. The average number of cases before the device needed repair was 5.3 for DUR-8E, 18 for URF-P5, 17.3 for Wolf Viper ${ }^{\circledR}$ and 17.6 for Stryker FlexVision U-500 ${ }^{\circledR}$. The authors commented that these FO-FUs were still fragile and still needed engineering improvements to improve durability (18). Multescu et al. (19) compared Storz Flex-XC ${ }^{\circledR}$, Olympus URF-V ${ }^{\circledR}$ and Wolf Cobra ${ }^{\circledR}$ for durability. The deflection loss after 30 procedures was lowest with Olympus URF-V ${ }^{\circledR}(5 \%)$ and was 9\% for Storz Flex-XC ${ }^{\circledR}$ and $10 \%$ for Wolf Cobra ${ }^{\circledR}$. The visual quality remained similar with D-FU but declined with Cobra with many broken optic fibers (9). In another study, same authors used 3 brand-new Storz Flex- $\mathrm{XC} \mathrm{C}^{\circledR}$ on 3 different series of patients. The first device was used in 96 cases, the second one in 151 procedures and the third series went on for 156 cases. The reason for repair for the first ureteroscope was damage to the outer coating on the contact point between the endoscope and the access sheath and the reasons were severe deteriorations in deflection with second and third endoscopes. The authors declared that this endoscope was proved to have increased durability (19). AlQahtani et al. (8) investigated the Olympus URF-V ${ }^{\circledR}$ in 2011 and performed 60 procedures for an average of $90.5 \mathrm{~min} /$ procedure. At the end of the evaluation period, maximal up-deflection was 
decreased from 1800 to 1610 and maximal down-deflection was decreased from 2750 to 2170 . The authors claimed that the device provided improved durability and performance compared to its ancestors (8).

The method of sterilization also has an important role in ureteroscope durability. Al Qahtani et al. (8) evaluated the difference between deflection rates of 2 different FUs, sterilized with either CIDEX OPA or STERRAD NX ${ }^{\mathrm{TM}}$. The subjective evaluations of maneuverability, laser duration and stone burden were similar, the usage time was higher for the first FU after 88 procedures. At the end of the study, when the upward and downward deflection capacities were measured, the FU sterilized with CIDEX OPA had better scores, so the authors concluded that CIDEX OPA should prioritize STERRAD in sterilization of D-FU.

\section{Maneuverability}

One of the most challenging situations during FURS is the approachability of a difficult-angled calyx, where range of motion of the FU is at its lowest and the risk of damage is high. PETRA group evaluated the capacity of various FUs on the market to reach the difficult lower pole calyces on a bench model. 9 FUs (Wolf Boa vision ${ }^{\circledR}$, Cobra vision ${ }^{\circledR}$, Storz Flex-XC ${ }^{\circledR}$, Flex-X2 ${ }^{\circledR}$, Boston Scientific Lithovue ${ }^{\circledR}$, Olympus URF-P5 ${ }^{\circledR}, \mathrm{P} 6^{\circledR}, \mathrm{V}^{\circledR}$ and $\mathrm{V} 2^{\circledR}$ ) were evaluated for the maximal end-tip deflection with the tip extended out from the sheath at 1, 2, 3 and $4 \mathrm{~cm}$. All the FOFU, except URF-P6 ${ }^{\circledast}$, reached the sharp angled calyx, however among the D-FUs, only Flex-XC ${ }^{\circledR}$ could reach the difficult calyx. Flex-XC ${ }^{\circledast}$ had similar end-tip deflection compared to FO-FU, whereas all the D-FUs had worse scores compared to FO-FU, which had a median of 210 more end-tip deflection. Storz Flex$\mathrm{X} 2{ }^{\circledR}$ had the best end-tip deflection among all ureteroscopes regardless of scoring systems (20).

Dragos et al. (20) also evaluated the torque abilities of different FUs inside a bench-model with increasing external pressure. The authors concluded at the end of their study that only Olympus URF-V2 ${ }^{\circledR}$ and Olympus URF-P6 ${ }^{\circledR}$ maintained their torque abilities but all the other FUs lost their rotational capacities when pressure was applied closest to the tip of the FU (21).

The disposable FU technology helped endourologists to use a brand-new device for each procedure, which led to the advantage of better maneuverability. Proietti et al. (22) evaluated the access and collecting system navigation capacity of Boston Scientific Lithovue ${ }^{\circledast}$, Olympus URF-P5 ${ }^{\circledast}$ and URF-V ${ }^{\circledast}$. The kidney access was possible for each ureteroscope, however, navigation inside the collecting system was not possible with the D-FU without an access sheath in 2 renal units. The navigation capacities were similar between the disposable D-FU and the reusable FO-FU (22).

\section{Size}

Size does matter. On a prospective randomized study, Bach et al. (23) compared the D-FU and FO-FU for the need of ureteral access sheath (UAS), need for postoperative stenting and complications. The authors used a $6.75 \mathrm{Fr}$ FO-FU and an $8.7 \mathrm{Fr}$ D-FU. Although the D-FU had advantages with better visual characteristics and durability, they were bigger due to their chip-on-the-tip technology. They required a UAS in 25\% of the cases whereas; only 7.5\% of FO-FU cases required a UAS. The rate of DJ stenting was 39 vs. $45 \%$ for FO-FU and D-FU, respectively. In conclusion of this article, D-FU required more UAS use which in turn increased morbidity, and expense and also increased post-operative DJ stenting (23).

In one of our previous studies, we placed 8 different FUs inside 5 different sized UAS and measured the pressure inside a bench model along with the irrigation backflow. Due to their larger sizes, the D-FU except Wolf Boa ${ }^{\circledR}$ vision did not fit into the smallest UAS, which is 9.5/11.5 Fr. The largest FU was Olympus URF-V ${ }^{\circledR}$, followed by Wolf Cobra vision ${ }^{\circledR}$. As the size of the FU increased, the size of the UAS increased gradually. However, even the size of the FU was small with Olympus URF-P6 ${ }^{\circledR}$, Storz Flex$\mathrm{X} 2{ }^{\circledR}$ and Wolf Boa vision ${ }^{\circledR}$, with 9.5/11.5 Fr UAS, the measured pressures were high. The irrigant backflow increased and pressures decreased as the size of the UAS increased, with the potential compromise of ureteral damage risk. The importance of the study was to point out the awareness to provide the most compatible coupling of FU and UAS size (24). In another previous prospective study published by our team, we measured the renal blood flow using Doppler ultrasound on renal and arcuate arteries before and after FURS, to see if small sized sheaths would cause any deterioration of blood flow due to increased intrarenal pressures during the operation. 3 different sized UAS (9.5/11.5, 10/12 and 12/14 Fr) and 2 different FUs were used (Storz Flex-X2 ${ }^{\circledR}$ and Flex-XC ${ }^{\circledR}$ ). No significant difference was noted on the renal artery measurements, however, in arcuate artery measurements, the resistive index increased in the post-operative period with 9.5/11.5 Fr UAS and Storz Flex-X $2^{\circledR}$ probably due to increased pressures and decreased irrigant backflow. The take-home-message was to have at least 1.5 Fr difference between the UAS and the FU to provide a safe combination in terms of intrarenal pressures (25). While evaluating the Olympus URF-V ${ }^{\circledR}$ for performance and durability, Al-Qahtani et al. (8) failed to access the ureter with the device in 5 of 60 patients and had to change to a FO-FU from the same company, Olympus URF-P $5^{\circledR}$, which has a smaller diameter.

\section{Conclusion}

Digital FUs provide various advantages especially in terms of visual quality and durability. The new generation D-FUs also have excellent maneuverability, similar to FO ureteroscopes, but they are larger in size, which in turn can affect morbidity due to increased post-operative stenting and increased complication risk with larger UAS and they come with higher costs. 
Many endourologists may prefer to use these high-tech, sophisticated devices as first-line for their flexible ureteroscopy procedures as they provide excellent surgical outcomes. However, due to excellent maneuverability advantages in complicated anatomies, smaller sizes and lower costs, endourologists should always try to keep a FO FU ready for action in their operating rooms.

Peer-review: Externally peer-reviewed.

\section{Authorship Contributions}

Concept: T.E.S.., A.P., M.T., Design: T.E.Ş., A.P., M.T., B.S., Y.T., Data Collection or Processing: T.E.S., A.P., Analysis or Interpretation: T.E.S., A.P., M.T., Literature Search: T.E.S., A.P., M.T., B.S., Y.T., Writing: T.E.S., M.T., A.P.

Conflict of Interest: No conflict of interest was declared by the authors.

Financial Disclosure: The authors declared that this study received no financial support.

\section{References}

1. European Association of U. History of Urology, http://history.uroweb.org. The EAU History Office.

2. Herr HW. Civiale, stones and statistics: the dawn of evidence-based medicine. BJU international 2009;104:300-302.

3. Marshall VF. Fiber Optics in Urology. J Urol 1964;91:110-114.

4. Takayasu H, Aso Y, Takagi T, Go T. Clinical application of fiber-optic pyeloureteroscope. Urol Int 1971;26:97-104.

5. Bagley DH. Flexible ureteropyeloscopy with modular, "disposable" endoscope. Urology 1987;29:296-300.

6. Mitchell $\mathrm{S}$, Havranek E, Patel A. First digital flexible ureterorenoscope: initial experience. J Endourol 2008;22:47-50.

7. Andonian $S$, Okeke Z, Smith AD. Digital ureteroscopy: the next step. $J$ Endourol 2008;22:603-606

8. Al-Qahtani SM, Geavlete B, Geavlette BP, de Medina SG, Traxer OP. The new Olympus digital flexible ureteroscope (URF-V): Initial experience. Urol Ann 2011;3:133-137.

9. Multescu R, Geavlete B, Geavlete P. A new era: performance and limitations of the latest models of flexible ureteroscopes. Urology 2013;82:1236-1239.

10. Talso $M$, Proietti $S$, Emiliani $E_{1}$ Gallioli $A$, Dragos $L$, Orosa $A$, Servian $P_{1}$ Barreiro A, Giusti G, Montanari E, Somani B, Traxer 0. Comparison of Flexible Ureterorenoscope Quality of Vision: An In Vitro Study. J Endourol 2018;32:523-528

11. Somani BK, Al-Qahtani SM, de Medina SDG, Traxer O. Outcomes of flexible ureterorenoscopy and laser fragmentation for renal stones: comparison between digital and conventional ureteroscope. Urology 2013;82:10171019.
12. de la Rosette J, Denstedt J, Geavlete P, Keeley F, Matsuda T, Pearle M, Preminger G, Traxer 0, CROES URS Study Group. The clinical research office of the endourological society ureteroscopy global study: indications, complications, and outcomes in 11,885 patients. J Endourol 2014;28:131139.

13. Proietti S, Somani B, Sofer M, Pietropaolo A, Rosso M, Saitta G, Gaboardi F, Traxer 0, Giusti G. The "Body Mass Index" of Flexible Ureteroscopes. J Endourol 2017;31:1090-1095.

14. Temiz MZ, Colakerol A, Ertas K, Tuken M, Yuruk E. Fiberoptic versus Digital: A Comparison of Durability and Cost Effectiveness of the Two Flexible Ureteroscopes. Urol Int 2019;102:181-186.

15. Taguchi K, Usawachintachit M, Tzou DT, Sherer BA, Metzler I, Isaacson D, Stoller ML, Chi T. Micro-Costing Analysis Demonstrates Comparable Costs for LithoVue Compared to Reusable Flexible Fiberoptic Ureteroscopes. J Endourol 2018;32:267-273.

16. Afane JS, Olweny EO, Bercowsky E, Sundaram CP, Dunn MD, Shalhav AL, McDougall EM, Clayman RV. Flexible ureteroscopes: a single center evaluation of the durability and function of the new endoscopes smaller than 9Fr. The Journal of urology 2000;164:1164-1168.

17. Monga M, Best $S$, Venkatesh $R$, Ames $C$, Lee $C$, Kuskowski M, Schwartz $S$, Vanlangendock R, Skenazy J, Landman J. Durability of flexible ureteroscopes: a randomized, prospective study. The Journal of urology 2006;176:137-141.

18. Knudsen B, Miyaoka R, Shah K, Holden T, Turk TM, Pedro RN, Kriedberg C, Hinck B, Ortiz-Alvarado O, Monga M. Durability of the next-generation flexible fiberoptic ureteroscopes: a randomized prospective multiinstitutional clinical trial. Urology 2010;75:534-538.

19. Multescu R, Geavlete B, Georgescu D, Geavlete P. Improved durability of flex-Xc digital flexible ureteroscope: how long can you expect it to last? Urology 2014;84:32-35.

20. Dragos LB, Somani BK, Sener ET, Buttice S, Proietti S, Ploumidis A, lacoboaie CT, Doizi S, Traxer 0. Which Flexible Ureteroscopes (Digital vs. Fiber-Optic) Can Easily Reach the Difficult Lower Pole Calices and Have Better EndTip Deflection: In Vitro Study on K-Box. A PETRA Evaluation. J Endourol 2017;31:630-637

21. Dragoş L, Martis S, Somani B, Bres-Niewada $E$, Sener T, Buttice $S$, Wiseman 0, Doizi S, Traxer 0. 'Torque'abilities of reusable and single-use flexible ureterorenoscopes: A novel in-vitro evaluation of twelve flexible ureterorenoscopes. European Urology Supplements 2018;17:e1794-e1796.

22. Proietti S, Dragos L, Molina W, Doizi S, Giusti G, Traxer O. Comparison of New Single-Use Digital Flexible Ureteroscope Versus Nondisposable Fiber Optic and Digital Ureteroscope in a Cadaveric Model. J Endourol 2016;30:655659.

23. Bach C, Nesar S, Kumar P, Goyal A, Kachrilas S, Papatsoris A, Masood J, Buchholz N. The new digital flexible ureteroscopes: 'size does matter'-increased ureteric access sheath use! Urologia internationalis 2012;89:408411.

24. Sener TE, Cloutier J, Villa L, Marson F, Buttice S, Doizi S, Traxer O. Can We Provide Low Intrarenal Pressures with Good Irrigation Flow by Decreasing the Size of Ureteral Access Sheaths? J Endourol 2016;30:49-55.

25. Sener TE, Tanidir Y, Bin Hamri S, Sever IH, Ozdemir B, Al-Humam A, Traxer 0 . Effects of flexible ureteroscopy on renal blood flow: a prospective evaluation. Scand J Urol 2018;52:213-218. 